\title{
The Function of the Medieval in Jean-Jacques Rousseau's Nouvelle Héloïse: A Rereading of the Abélard and Héloïse Motif
}

\author{
Alicia C. Montoya
}

Published online: 29 April 2010

(C) The Author(s) 2010. This article is published with open access at Springerlink.com

\begin{abstract}
Jean-Jacques Rousseau's critical rewriting in his Nouvelle Héloüse of two foundational medieval works - the letters of Abélard and Héloïse, and Petrarch's Canzoniere-reveals the crucial role that the medieval played in his own moral vision. This article both identifies a possible eighteenth-century source for Rousseau's retelling of the Abélard and Héloïse story, and explores the function played by the medieval in his novel. The medieval in La Nouvelle Héloïse, as in his larger thought, was not a chronological, but an ethical category. It spoke not of historical events, but of his own "pays des chimères". Because of its position outside of the accepted classical canons, it could incarnate an alternative vision commensurate with Rousseau's own self-image as an outsider to the morally corrupted societies of his own time. Associated with the purer language of music, the medieval finally offered access to a higher spiritual plane, exemplified by Julie's role as a Mary-like or even Christ-like figure. As such, the medieval ultimately served as an epistemological counter-model, an imaginary point of origin within a larger history of human virtue.
\end{abstract}

Keywords Rousseau · Abélard and Héloïse · Petrarch · La Nouvelle Héloïse · Medievalism

The influence of classical models on the oeuvre of Jean-Jacques Rousseau has frequently and convincingly been studied. By contrast, the role of the medieval is more often overlooked. Yet even the most cursory glance at the titles of his works suggests that certain, particularly archetypal medieval texts carried a special

\footnotetext{
A. C. Montoya $(\bowtie)$

Department of Romance Languages and Cultures, Faculty of Arts, University of Groningen, P.O. Box 716, 9700 AS Groningen, The Netherlands

e-mail: A.C.Montoya@rug.nl
} 
resonance for him. Julie, ou La Nouvelle Héloüse directly alludes to the story of the twelfth-century lovers Abélard and Héloïse. The title of his Confessions announces the influence of Saint Augustine's work on the structure and content of his book-as has indeed recently been explored by Patrick Riley, among others (Riley 2004). In personal life, too, Rousseau was deeply attached to the medieval. Torquato Tasso's chivalric epic Gerusalemme Liberata remained a constant literary model for him, even during the last months of his life, when he had turned his back on all other literature (Hamman 2006; Montoya 2010a; Starobinski 1994). Another major influence was Honoré d'Urfé's Astrée, whose description of the pastoral loves of shepherds and druids in fifth-century Gaul underlay his own pastoral writings (McDonald Vance 1973). It is perhaps in his epistolary novel Julie, ou la Nouvelle Héloïse, which in many aspects offers a synthesis of his thought and vision, that Rousseau's medievalism was at its most paradigmatic. By critically rewriting two foundational medieval works - the letters of Abélard and Héloïse, and Petrarch's Canzoniere-Rousseau offered a new view of the Middle Ages that is both of his time and outside it, and that played a defining role in his own authorial selffashioning and larger moral vision.

\section{Eighteenth-century Versions of the Abélard and Hélöise Story}

Rousseau started writing Julie, ou la nouvelle Hélö̈se in the summer of 1756, by his own account in the Confessions while imagining fictional characters and situations to compensate for an unrequited love involvement of his own:

L'impossibilité d'atteindre aux êtres réels me jeta dans le pays des chimères, et ne voyant rien d'existant qui fût digne de mon délire, je le nourris dans un monde idéal, que mon imagination créatrice eut bientôt peuplé d'êtres selon mon cœur. ${ }^{1}$

Published at the beginning of 1761 , this novel conceived in the "pays des chimères" appeared during a period in which literary interest in the Middle Ages was on the rise, in many respects reworking and updating the previous century's ideal of galanterie. Emphasizing notions such as an idealized return to a previous state of pastoral bliss and the equalizing power of love, medievalism was an important element within mondain literary sensibility. Not surprisingly, given the importance of romantic love for the galant esthetic, two medieval couples of lovers came to play a central role in it: Abélard and Héloïse, and Petrarch and Laura. Following the rediscovery of the former's letters at the end of the seventeenth century, ${ }^{2}$ their love story came to the forefront of literary discourse, reaching new heights of popularity during the 1750s. By the date of publication of Rousseau's novel, at least six French translations had been produced of Alexander Pope's extremely popular "Eloisa to Abelard" (originally 1717), ${ }^{3}$ while other texts, including Pierre François Godard de

\footnotetext{
1 Rousseau (1973), 517.

2 For an overview, see Charrier (1933).

3 Anderson (1971), 19.
} 
Beauchamps's fictionalized Lettres d'Héloüse et d'Abailard (1714) were still in circulation. At the same time, by inspiring Guilleragues's earlier Lettres d'une religieuse portugaise (1669), the story of Abélard and Héloïse played a crucial role in shaping the eighteenth-century epistolary novel-as has indeed been noted by scholars who have explored the novel's influence on Rousseau. In these literary versions of the story, it was above all Héloïse's passionate love for Abélard that was foregrounded, and she was subsequently viewed as the narrative's true protagonist. ${ }^{4}$ Such was the resonance of Héloïse's story that Aimé Ambroise Joseph Feutry's 1751 translation of Pope's "Eloisa" tellingly referred to a subject that was by that date "usé et rebatu", 5 while in the Encyclopédie article "Scholastiques", Diderot rhetorically asked his readers: "Qui est-ce qui ne connoit pas l'histoire \& les malheurs d'Abélard? qui est-ce qui n'a pas lu les lettres d'Héloïse?"6

There was, however, another tradition of retellings of the Abélard and Héloïse story that has, perhaps, not received the attention it deserves in accounts of the eighteenth-century Abélard and Héloïse revival. This is the tradition of monastic historiography, within which the original twelfth-century letters had possibly themselves been conceived. Because of their emphasis on the construction of a female passionate subjectivity, galant accounts had little to say about Abélard and Héloïse's historical role as founders of the abbey of the Paraclet. Yet this was the sole role in which they were remembered at the abbey itself, according to some eighteenth-century accounts. ${ }^{7}$ This alternative version of the story was best exemplified by the former Trappist monk François Armand Gervaise's meticulously documented, two-volume Vie de Pierre Abeillard, abbé de S. Gildas de Ruis, ordre de S. Benoist; et celle d'Héloüse son epouse, premiere abbesse du Paraclet, that was first published in 1720. This work was followed three years later by a bilingual edition of the original twelfth-century letters- the only printed translation available in Rousseau's day. ${ }^{8}$ Running to over 500 pages, Gervaise's Vie de Pierre Abeillard explicitly sought to resituate Abélard's career within the broader framework of ecclesiastic historiography. By focusing not on Abélard the lover, but on the man of faith, Gervaise sought to revise the accounts of his predecessors. These included, among secular versions, Roger de Bussy Rabutin's seventeenth-century, galant translations of Héloïse's letters, which had originally rekindled literary interest in the theme, as well as Pierre Bayle's anti-clerical rendering of the story in his Dictionnaire historique et critique. In addition, Jean Mabillon's critical account of Abélard in his biography of Saint Bernard of Clairvaux, too, was the object of

\footnotetext{
4 In some non-literary accounts, notably Pierre Bayle's four articles on the subject in his Dictionnaire historique et critique ("Abelard", "Foulques", "Helö̈se", "Paraclet"), the focus is rather on Abélard's castration (Bayle 1740). See Walter (1980) for more examples.

5 Cited in Anderson (1971), 19.

6 Alembert and Diderot (1751-1765), XIV, 771.

7 Feilla (2004) notes that "in 1767, an English visitor to the convent noted with surprise that apart from the abbess, the nuns of the Paraclete knew nothing of the 'affecting part' of the story of Abelard and Heloise. The sisters knew the pair in terms of their institutional roles in the abbey as its founder and first abbess, but not as lovers" (10).

8 The original Latin letters were available in a 1616 French edition (Paris: Nicolas Buon), as well as a more recent English one (London: E. Curll and W. Taylor, 1718).
} 
critique. Gervaise's text and subsequent edition of the letters is thus to some extent an anomalous, polemic one. Yet in its very anomalousness, it appears to presage the ways in which Rousseau's later version would also deviate from popular accounts, thereby making Gervaise's three volumes, thus far neglected by Rousseau scholars, a possible source for his account of the medieval story.

Renewed interest in the Abélard and Héloïse story was in turn related to the rediscovery of another medieval couple of lovers: Petrarch and Laura. Petrarch himself had of course already commented on the story of the famous French lovers, thereby linking up with a French literary tradition that went back at least to the Roman de la Rose. Eighteenth-century authors, for their part, willingly reinscribed Petrarch and Laura into national traditions. Petrarch's immortalization of his beloved Laura in his Canzoniere or Rime sparse had gained a new purchase on literary imagination through his long-standing association with the troubadours, as postulated among others in Jean de Nostredame's highly influential Vies des plus célèbres et anciens poètes provençaux (1575). Indeed, during the same decades that witnessed the rediscovery of Abélard and Héloïse's letters, the memory of the troubadours began to be revived in dozens of works, gaining further momentum with the early Enlightenment search for national foundations for French literary historiography. By considering Petrarch as the last great troubadour, or the poet who had carried the troubadours' poetic traditions to a new summum of perfection, French historiographers annexed him to their own medieval past, thereby giving it a new respectability. Thus, a text such as Joseph Bimard de La Bastie's "Vie de Pétrarque", for example, published in 1743 and 1751 in the Mémoires de l'Académie Royale des Inscriptions, was part of a larger series in the same periodical, detailing the lives of the medieval French poets, from Christine de Pizan to Guillaume de Machaut and Charles d'Orléans.

Just as importantly, through literary reworkings of his poetically enshrined love for Laura, starting with Madeleine de Scudéry's Mathilde (1667) and Bernard de Fontenelle's dialogue of the dead between Sappho and Laura (1683), authors created a female protagonist and a love story that readily lent itself to fictionalization, and could indeed-like Abélard and Héloïse's - be seen as an archetypal figure for all love stories. In many of these accounts, the medieval was a constitutive element of the narrative, producing sometimes highly curious amalgams. In Lefranc de Pompignan's popular Voyage de Languedoc et de Provence (1745), for example, Petrarch and Laura were presented in an Eden-like French pastoral setting-Ile sur Sorgue, that in the seventeenth century had already become a destination for literary pilgrimagescomplete with characters drawn straight out of d'Urfé's Astrée, including medieval druids, feats of magic and of course the required love plot.

\section{Structural and Thematic Parallels}

Given the broader cultural context of eighteenth-century medievalism, Rousseau's choice to foreground the already highly visible medieval stories of Abélard and Héloïse and of Petrarch on the title-pages of his own Nouvelle Héloïse is surely significant. Rousseau scholarship has regularly noted the relation between 
Rousseau's text and his medieval models, but has failed thus far to move beyond noting general parallels toward an examination of the implications of these borrowings and their role within Rousseau's literary vision. ${ }^{9}$ Conspicuously absent in discussions to date has been an attempt to identify the actual texts Rousseau may have consulted, and the presence of direct citations from them in La Nouvelle Héloïse. In the following pages, I will therefore start by briefly sketching once again some general parallels, before moving onto a discussion of specific instances of intertextuality, and a broader consideration of the meaning of the medieval for Rousseau in this novel.

Rousseau himself emphasized his novel's relation to its medieval intertexts. On the liminary half-title page, the shortened title Julie, ou La Nouvelle Héloïse, by its use of the adjective "nouvelle" (originally "moderne", and changed to "nouvelle" during the typesetting), ${ }^{10}$ contained an explicit allusion to the old or non-modern Héloïse, i.e. the twelfth-century nun. Then, on the main title page, the long titleLettres de deux amans, Habitans d'une petite Ville au pied des Alpes-was followed by an epigraph taken from the concluding section of Petrarch's Canzoniere:

Non la connobe il mondo, mentre l'ebbe:

Connbill'io ch'a pianger qui rimasi. ${ }^{11}$

The verse from Petrarch cited by Rousseau, as noted by his modern editor Henri Coulet, in turn recalled two passages from the prologue of the Gospel according to John: "He was in the world, and the world was made by him, and the world knew him not" (I: 10), and: "And I knew him not, but that he may be made manifest in Israel, therefore am I come baptizing with water" (I: 31). Rousseau's protagonist Julie, as underlined by this reference, is presented in the novel as a Christ-like figure, who sacrifices herself for the good of others. Significantly, her death results from the pneumonia she contracts after saving her son from drowning. This is not only an immersion with obvious parallels to the Christian ritual of purification by water, but her illness - pneumonia_also suggests a rapport with the notion of divine breath/ inspiration or pneuma. The juxtaposition of the two female medieval figures, Héloïse and Laura, on the novel's title pages, would thus seem to steer the readers of Rousseau's novel toward a reading that places it firmly within a Christian context.

While it is true that Rousseau only decided on the shortened title-La Nouvelle Héloïse-relatively late, ${ }^{12}$ the overdetermination of the title-page references to medieval texts should probably be read as an explicit confirmation, after the fact, of a basic plot structure and content that were already in place, and that displayed significant similarities with their medieval models. The main plot, to begin with,

\footnotetext{
${ }^{9}$ For discussions of the relation between the Abélard and Hélöise theme and Rousseau's novel, see besides Charrier (1977), also Anderson (1971), Kamuf (1982), Spaas (1999), Koschorke (2000), Challandes (2002).

10 Stewart (1995), 36.

11 Petrarca (1992), 421. All references are to this edition. Rousseau read the original Italian version, which was widely available in the eighteenth century in several editions.

12 Stewart (1995).
} 
follows the same general lines as the twelfth-century letters. A young philosopherteacher, Abélard-Saint-Preux, seduces his pupil, Héloïse-Julie. The seduction is discovered, the seducer is punished, and the two protagonists go on to live cloistered lives, in the newly-founded abbey of the Paraclet in the case of Héloise, and at the country estate of Clarens, which includes a typical medieval hortus clausus, in the case of the eighteenth-century characters. The correspondences between the characters in the two versions of the story are clear. Saint-Preux's relation to the scholastic philosopher Abélard is highlighted by the characters' repeatedly referring to him as "notre philosophe", while he alludes pointedly to himself as a "maître de philosophie" (I: 131). ${ }^{13}$ His name-Saint-Preux, or saint valiant knight-further underlines the medieval provenance of the character. This influence is finally suggested, too, in a parodic mode, by the passage in which Julie addresses him in mock old-French language, emphasizing their roles as typical courtly lovers (I: 160). ${ }^{14}$ The analogy between Julie and Héloïse, for its part, is made both by the title's juxtaposition of their two names-Julie, ou la Nouvelle Héloïse-and by more explicit comparisons in the novel itself.

More importantly, both texts follow the pattern of conversion narratives, a narrative model with which Rousseau was very familiar, and which he was later to practice in his Confessions. Both the collected volume of Abélard and Héloïse's letters and Rousseau's Nouvelle Hélö̈se have a dual structure, ultimately based on the bipartite ordering of the Christian Bible into an Old and a New Testament, with the second part analogically echoing the first. In his Vie de Pierre Abeillard, Gervaise indeed very pointedly insisted on this element of conversion, which he opposed to previous galant accounts that had instead focused on Abélard's role as lover:

C'est une chose surprenante que depuis tant de siécles, personne n'ait pensé à nous donner une véritable histoire du fameux Abeillard, \& qu'on ne se soit arrêté qu'à l'endroit de ses jours le moins édifiant, pour composer des pieces galantes uniquement propres à nourrir une flâme impure, tandis qu'on a laissé dans l'oubli sa conversion qui fait tant d'honneur à la grace de Jesus-Christ. ${ }^{15}$

Thus, the first part of Abélard and Héloïse's exchange of letters tells of a fall from grace. The second, much longer part then tells how the sinners/a saviour figure make up again for this fall by a new sacrifice. In the twelfth-century story, the redemption is achieved by Héloïse's separation from Abélard, her vows and subsequent leadership of an abbey. In La Nouvelle Hélö̈se the redemption consists in Julie's marriage, motherhood, and ultimately, death. In both cases, following the confessional mode established by Saint Augustine, the redemption in the second part is made more striking for the depths to which the sinners had fallen in the first part. Héloïse insists on her own previous sinfulness-even seems to revel in it-in order to make the story of her turning to God a more powerful one. The single most

\footnotetext{
13 All references are to volume and page number in Henri Coulet's two-volume edition of La Nouvelle Hélö̈se (Rousseau 1993).

14 On the theme of courtly love in the novel, see L'Aminot (2002) and Leborgne (2002).

15 Gervaise (1720), non paginated.
} 
quoted passage from her letters, and the passage that largely cemented the eighteenth-century and Romantic view of her as passionate woman-out-of-control, occurred when she described herself in her first letter as a concubine to Abélard-a term that was not infrequently translated as "whore" by later adapters and fictionalizers (including Bayle):

Le nom \& la qualité d'épouse, je l'avoüe, ont quelque chose de plus saint \& de plus solide que le nom de maîtresse: cependant celui-ci m'étoit infinement plus cher \& plus doux que l'autre, parce que je vous faisois un plus grand sacrifice.

Et si uxoris nomen sanctius ac validius videtur, dulcius mihi semper extitit amicæ vocabulum; aut, si non indigneris, concubinæ vel scorti. ${ }^{16}$

Héloïse's words, repeated, quoted and embellished by the numerous authors who produced new versions of her story during the following centuries, became a topos of subsequent retellings. As Cecilia Feilla has written, "it was the seduced and abandoned Heloise of the early letters that captured the popular imagination of eighteenth-century readers, not the abbess of the later letters concerned with the spiritual life of her religious community" (3). Yet Gervaise already had suggested an alternative reading by repeatedly softening the words, in his Vie d'Abeillard, and making Héloïse plea instead to Abélard "que je sois toûjours vôtre amie, \& jamais vótre épouse"(I: 68; II: 28). Directly aimed at Pierre Bayle, in whose account Héloïse "aimeroit mieux être la putain de Pierre Abelard, que la femme légitime de l'Empereur de toute la Terre" (714, note K), Gervaise's account sought to reinscribe the story within a religious tradition of monastic historiography. It is all the more remarkable, then, that among the eighteenth-century literary authors who reworked the Héloïse story, Rousseau was the only one who, following Gervaise's example, also incorporated, and in fact gave a major role, to the second part, which tells of the characters' moral redemption after their sinful passion. Just as in the original exchange, which ends with the description of the rule to be observed by the nuns of the Paraclet, La Nouvelle Héloïse too concludes with several letters describing the precepts and way of life obtaining at Clarens, regularly punctuating the narrative with the key terms "règle" and "règle de vie" (II: 68, 83, 133, 152, etc.). The garden that Julie builds at Clarens, her significantly named Elysée, likewise appears to echo "ce nouveau jardin qu'Abeillard avoit planté, qu'il arrosoit par ses prédications, \& que la grace faisoit fructifier" in Gervaise's account, i.e. the religious community of the Paraclet itself. ${ }^{17}$ In this sense, Rousseau's novel too can be read as the history of the foundation of a religious community.

The second major intertext in Rousseau's Nouvelle Héloïse was provided by the love poems Petrarch wrote over the course of several decades for his beloved Laura, and then published in his Canzoniere. ${ }^{18}$ Rousseau directly cited Petrarch on nine

\footnotetext{
16 Gervaise (1723), I: 26. All citations of Héloïse and Abélard's letters are taken from this eighteenthcentury edition and translation, on the assumption that it was the one Rousseau consulted.

17 Gervaise (1720), I: 246.

18 Rousseau's debt to Petrarch has not received nearly as much attention as the influence of the Abélard and Héloïse story. For a brief account, however, see among others Duperray (1997) and Stackelberg (2001).
} 
occasions, making the Canzoniere, along with Tasso's Gerusalemme Liberata, the second most quoted text in his book, excluding the Bible. Aside from direct citation, there are several passages in the Nouvelle Héloüse that read as prosified imitations of Petrarch poems. In the fourteenth letter especially, which comes after the lover's first kiss, Saint-Preux adopted the central Petrarchan conceit of the poisonous, bitter-sweet kiss of love-the "baisers [...] trop âcres, trop pénétrants" (I: 109), which simultaneously give life and death. In addition, Rousseau played with many topoi of the Petrarchan-troubadour tradition, from the conventional birth of love in springtime (I: 166) to the description of the beloved lady from head to foot (I: 198), according to Matthew of Vendôme's "a capite usque ad pedes" system. Equally significant, perhaps, is the fact that like La Nouvelle Héloïse, Petrarch's Canzoniere told the story of a romance, in which a young man fell in love, experienced passion, and then endured an ultimate separation from his beloved one. Like the letters of Abélard and Héloïse, this story too had a two-part structure, with spiritual elevation following earthly passion. In addition, a number of details within the text of the novel, including the episode with the courtisane Laure-Laureta Pisana in the fifth book, suggested readings in which more precise parallels could be drawn between the medieval love poems for Laura-Laureta and Rousseau's novel.

\section{A Meditation on Origins}

If the structural parallels between Rousseau's novel and his medieval sources, as mediated most notably through Gervaise's account and translation of Abélard and Héloïse's letters, strongly suggest that his medievalism was more than merely a superficial tribute to literary fashion, it also raises the deeper question of its function in the text. A first clue to its significance is provided by Rousseau's lifelong fascination with the philosophical question of origins: the origins of society, of inequality, of moral corruption, of language, and even of the literary genres he practiced. Thus, in La Nouvelle Héloïse, Rousseau turned to the origins of the epistolary genre, for the correspondence of Abélard and Héloïse could indeed be read as "history's first epistolary novel". ${ }^{19}$ His Confessions likewise, by explicitly imitating Saint Augustine, went back to the medieval origins of the autobiography, skipping over the intervening centuries and authors-most notably, in the French context, Montaigne, whom he referenced but only to dismiss as inauthentic. This is significant: by skipping over the intervening centuries, which had inaugurated the modern era, Rousseau was implicitly criticizing them and his own time, as he indeed did in his other writings. In his first published work already, the Discours sur les arts et les sciences, he had drawn an implicit link between the advent of the Renaissance and the moral degradation of European societies (Montoya 2010b). While, as Bruce Holsinger has argued, Rousseau's works also betrayed a "pathologizing invocation of the Gothic_as sickness, as perversion, as destruction", ${ }^{20}$ his invocation of the Middle Ages was in fact strongly ambivalent. Like the

\footnotetext{
19 Powell (2000), 257.

${ }^{20}$ Holsinger (2005), 145.
} 
filthy and antisocial philosopher Diogenes, or like Sparta (as opposed to democratic Athens), two anti-models also evoked by him, the Middle Ages did not ever completely shed their negative associations. On the contrary, it was precisely this position of the medieval outside of the accepted classicist canons that made them capable of incarnating a powerful alternative vision. For Rousseau, the self-styled, rustic "citoyen de Genève" who criticized the fashionable Parisian philosophes, the medieval was closely linked both to his mythical Golden Age, and to the "pays des chimères" in which his novel had originated and which, according to Julie, held out the only possibility of human fulfillment in this world: "Le pays des chimères est en ce monde le seul digne d'être habité, et tel est le néant des choses humaines, qu'hors l'Etre existant par lui-même, il n'y a rien de beau que ce qui n'est pas" (II: 333). The invocation of the medieval, as an atemporal and possibly even non-existent "pays des chimères", allowed Rousseau to criticize Enlightenment progressivism, and at the same time to present himself as an outsider to the morally corrupted societies — urban modernity itself_-of his own day.

The medieval as a site paradoxically located outside of historical time is also at work in the novel's setting. While the action of La Nouvelle Héloise took place in the eighteenth century, Rousseau suggested that the particular setting which he had chosen had something archaic about it. The Pays de Vaud, in Switzerland, was associated in his mind with his own childhood and with his long-dead "pauvre Maman" (the real one, not Mme de Warens), ${ }^{21}$ whose birthplace Vevey was the "petite Ville au pied des Alpes" where the first part of the novel took place. Consequently, the novel was suffused with a sense of nostalgia that was also typical of medievalist fiction, and that relied on the increasingly common identification of childhood or the "enfance de l'homme" with the Middle Ages. The topos of the medieval as the site of childhood and of imagination thus reinforced the archaicizing description of Switzerland as "un pays libre et simple, où l'on trouve des hommes antiques dans les temps modernes" (I: 104), and of SaintPreux's preserving "la simplicité des antiques mœurs helvétiques" (I: 358) even during his Parisian sojourn. While the adjective "antique" could refer both to classical antiquity and to the medieval past in eighteenth-century usage, in the preface Rousseau suggested that he was referring to the latter, when he wrote about his novel:

Le style rebutera les gens de goût, la matière alarmera les gens sévères, tous les sentiments seront hors de la nature pour ceux qui ne croient pas à la vertu. [...] Ce recueil avec son gothique ton convient mieux aux femmes que les livres de philosophie. (I: 72, emphasis added)

In an ironic opposition typical of his writing, Rousseau contrasted philosophy books, which conveyed only false knowledge, and his own book, which-despite of, or rather because it was written in a Gothic style-was capable of revealing deeper truths. This contrast between true and false knowledge was itself of course also an ancient topos that went back, among others, to Abélard's letters. Throughout his letters, Abélard created an opposition between his own position as a philosopher who fully believed in book learning, and other, "antique" models that saw wisdom rather as a way of life: a position that Rousseau rejected when he consciously

${ }^{21}$ Rousseau (1973), 521. 
presented himself as a neo-antique anti-philosopher or even anti-Abélard. The contrast between the Augustinian Book of Nature, which provided direct and unmediated access to the divine, and deceptive book-learning, recurred frequently in Rousseau's oeuvre, and suggested another contrast between the paradoxical truth of the medieval "pays des chimères" and the false realism of modernity.

Rousseau's concern with origins finally elucidates, too, his citations of Petrarch. In later editions of the novel, he added a short dialogue text in which two characters-identified by the initials N. and R.- discussed the question whether novels, as the product of modern, corrupting civilization, could have a morally edifying function. At one point, R.- who could perhaps be identified with Rousseau himself-described the particular nature of La Nouvelle Héloïse:

[Ces] lettres n'intéressent pas tout d'un coup [...] La grâce et la facilité n'y sont pas, ni la raison, ni l'esprit, ni l'éloquence; le sentiment y est, il se communique au cœur par degrés, et lui seul à la fin supplée à tout. C'est une longue romance dont les couplets pris à part n'ont rien qui touche, mais dont la suite produit à la fin son effet. (II: 401)

The romance, which Rousseau defined in his Dictionnaire de musique as "une mélodie douce, naturelle", "écrite d'un style simple, touchant, et d'un goût un peu antique" 22 was a medievalist musical genre that used a succession of couplets to tell a simple (love) tale, thereby recalling other serial poetic compositions like Petrarch's Canzoniere. Importantly, the romance had affinities both with lyrical and with narrative genres. By using this term, Rousseau seemed to suggest that La Nouvelle Héloïse was not really a novel but rather, a lyrical composition where what mattered was not the content, but the mood expressed. The notion of literary genre, with its emphasis on form and content, was thus replaced by that of musical register or mood. Indeed, what was crucial in this redefinition of his novel was that the romance was sung. As Rousseau had written elsewhere, what attracted him in Petrarch was above all the musicality of his language, and in imitating him, it was this musicality that he was attempting to approach.

Now music, associated with romance, in its turn held a specific value for Rousseau. In the key episode of the vendanges at Clarens, Saint-Preux described how after harvesting the grapes, the workers on the estate enjoyed a communal meal and started to sing popular songs or romances:

Quelquefois les vendangeuses chantent en chœur toutes ensembles, ou bien alternativement à voix seule et en refrain. La plupart de ces chansons sont de vieilles romances dont les airs ne sont pas piquants; mais ils ont je ne sais quoi d'antique et de doux qui touche à la longue. Les paroles sont simples, nä̈ves, souvent tristes; elles plaisent pourtant. (II: 240, emphasis added)

Romance was significantly equated with a remote past-antiquity, which could be conceived either as medieval or Greco-Latin-and this remote past in turn was described as naive, a time of spiritual purity. The pastoral notion of a purer, past

22 Rousseau (1995), 1028. 
state of human society and human morality was reinforced by the central image of the vineyard. Recalling the Gospel image of the workers labouring in the vineyards of the Lord, the vineyard was the source of the main agricultural product harvested at Clarens. Clarens's own name in turn, as argued by Jean Starobinski, played on notions of clarity and spiritual transparency-we are now in the second, redemptive part of the novel-replacing former obscurity. ${ }^{23}$ The association between song, moral purity and transparency was the same one that Rousseau had discussed in his Essai sur l'origine des langues. According to him, before humankind could speak, it sang: music was an archaic, purer language, and one that came closer to expressing true human feelings than later, corrupted human languages did. By singing medieval romances his peasants approached a state of human authenticity-a state poised halfway between nature and civilization-inaccessible to eighteenth-century Parisians. Although there is a whiff of the medieval - the autarchic mini-state of Clarens is organized along basically feudal lines-the description of the vendanges, as again argued by Starobinski, is singularly lacking in exact historical references, situating it more immediately in Rousseau's "pays des chimères." The medieval, as an aspect of Rousseau's Golden Age, is thus properly a moral category rather than a temporal or historical one, and it was precisely its ahistorical nature that gave it polemic weight. It was, in fact, because the "real", historical Middle Ages remained largely unknown to eighteenth-century authors that the medieval so readily assumed this contestatory role as a site of idealized human fulfillment.

\section{A Critical Rewriting of Medieval Sources}

But at the same time as the Nouvelle Hélö̈se offered a reflection on origins, it also offered a more textually precise, critical rewriting of the medieval texts it referenced. In the case of the letters of Abélard and Héloïse, the structural parallels actually highlighted important differences between the two texts. At a number of critical junctions in the narrative, the characters referred explicitly to the medieval prototype, but only to distance themselves from it. Thus, finding himself on the brink of giving in to his lustful passion for Julie, Saint-Preux reminded himself of Abélard, whose example he did not wish to follow.

Quand les lettres d'Héloïse et d'Abélard tombèrent entre vos mains, vous savez ce que je vous dis de cette lecture et de la conduite du Théologien. J'ai toujours plaint Héloïse; elle avait un cœur fait pour aimer: mais Abélard ne m'a jamais paru qu'un misérable digne de son sort, et connaissant aussi peu l'amour que la vertu. Après l'avoir jugé faudra-t-il que je l'imite? malheur à quiconque prêche une morale qu'il ne veut pas pratiquer! (I: 132)

Of course, the irony is that Saint-Preux would in fact end up following Abélard's pernicious example when he, too, would seduce his young charge. After Julie's marriage to Wolmar, her cousin Claire made a second comparison:

\footnotetext{
${ }^{23}$ Starobinski (1971), 105.
} 
Cousine, tu fus amante comme Héloïse, te voilà dévote comme elle; plaise à

Dieu que ce soit avec plus de succès! (II: 120)

Claire's words contained an implicit criticism: Héloïse was not really devout, but only thought she was, while Julie truly was devout. The Nouvelle Héloïse thereby offered a critical rewriting of the popular eighteenth-century image of Héloïse, and possibly of the medieval letters too; this was the strong, programmatic sense Rousseau gave to the adjective "nouvelle" in the novel's title.

The most significant difference between the medieval Héloïse and her eighteenth-century counterpart in La Nouvelle Hélö̈se is that while the medieval Héloïse, as abbess or mother superior, played the part of mother only in a metaphorical sense, Julie really was a true mother. In the second half of the novel, Rousseau placed great emphasis on Julie's devotion to her two children, whom she raised and educated herself, rather than entrusting them to the care of others as was contemporary aristocratic practice. To reinforce this new interpretation, Rousseau altered his citations of the medieval text. As mentioned above, in the eighteenthcentury literary tradition that arose around Héloïse's letters, the passage that was most consistently cited by her imitators was her declaration that she would rather be called Abélard's mistress than his wife. Reread in its original twelfth-century context, however, this passage assumed a place within a much larger theme of onomastic uncertainty. In the very first words she wrote to Abélard, Héloïse hesitated on how to address him:

Domino suo, imo patri; Conjugi suo, imo Fratri; Ancilla sua, imo Filia; ipsius uxor, imo Soror; ABÆLLARDO Heloïssa.

A son Seigneur, ou plutôt à son pere; à son époux, ou plutôt à son frere; sa servante, ou plutôt sa fille; son épouse, ou plutôt sa sœur. HELOISE à son Abeillard. ${ }^{24}$

Gervaise insisted on the significance of this onomastic hesitation by including it not only in his translation, but by commenting on it also, at some length, in his Vie de Pierre Abeillard (I: 26-28). This hesitancy was echoed in Rousseau's text, too. Thus, upon consummating his love with Julie, Saint-Preux no longer knew what to call her: "O ma charmante maîtresse, ô mon épouse, ma sœur, ma douce amie!" (I: 200) he cried out in apparent distress. This, I would contend, is a direct reference to the medieval text, as mediated to Rousseau through Gervaise's edition and French-language translation. Interestingly, the final published version left out two terms that had been present in Rousseau's original manuscript:

O ma charmante maîtresse, ô mon épouse $<$ ma mère, ma fille $>$, ma sœur, ma douce amie! (I: 494)

These were, in fact, the two terms that had been foregrounded in Abélard's letters (and Gervaise's subsequent biography and edition), where he had juxtaposed them to the more conventional image of the nun as sister (although in this text, the

${ }^{24}$ Gervaise (1723), 3-4. 
absence of the most obvious term - that of bride of Christ — was perhaps revelatory of Abélard's own compromised position):

Heloïse, ajoûte-t-il [Abélard], étoit si estimée \& si chérie de tout le monde, que les Evêques la considéroient, \& l'honnoroient comme leur fille, les Abbés comme leur sœur, \& les personnes du siécle comme leur mere. ${ }^{25}$

By underlining these words in his Vie de Pierre Abeillard, Gervaise was proposing a revisionary, rechristianized reading of the Abélard and Héloïse story that was strikingly similar to the one proposed by Rousseau. Rousseau did consciously delete the female protagonist's roles as monastic mother and daughter in Saint-Preux's letter, but did so apparently only to be able to insist the more on their importance in later passages. Shortly thereafter, in fact, he reintroduced these monastic roles, in a context that gave them a new narrative weight. Julie, in the following letter, reproached her lover by using a new term:

Tu m'as honoré quelquefois du tendre nom d'épouse: peut-être en ce moment dois-je porter celui de mère. (I: 212-213)

And as if to insist on the transformation that his protagonist had undergone, Rousseau had Julie furthermore announce to her cousin Claire, at the start of the fourth part, inaugurating Saint-Preux's own spiritual transformation: "Tu m'as vue successivement fille, amie, amante, épouse, et mère. Tu sais si tous ces titres m'ont été chers!" (IV: 1, emphasis added). While the medieval text underscored the roles of spouse and mistress in Héloïse's famous letter, the eighteenth-century novel finally replaced the mistress by the mother. This was an assumption of agency on Julie's part that produced an inversion of the medieval text similar to the one described by Laure Challandes: "l'influence intertextuelle se fait sur le mode du renversement des genres: Saint-Preux incarne la voix et la position énonciative d'Héloïse, et Julie, celle d'Abélard" (79). The mother role Julie came to play in the novel ultimately coalesced into another role: that of Mary. At the end of Petrarch's Canzoniere, the beloved Laura-who was by then dead-was identified with the Virgin Mary, transforming the poet's sexual desire into a purer striving for grace. In La Nouvelle Héloüse too, as in Petrarch's poetic sequence, the male protagonist finally renounced physical pleasure, and attained a more mystical union with a Mary-like figure. And as in the medieval fin amors tradition of the highborn lady courted by a lowly troubadour, love elevated the lover to a higher spiritual plane (I: 435).

Rousseau's rewriting operated, then, through a kind of literalization. Where the twelfth-century letters had described Héloïse's metaphorical motherhood as abbess or mother superior, Rousseau insisted on Héloïse's literal motherhood. The medieval model of female monasticism — symbolic motherhood-was replaced by a modern vision of piety: true, physical motherhood in an ostensibly secular setting. Whereas the twelfth-century letters had told only of a metaphorical deathHéloïse's death to the world when she took the veil-the novel told of real physical sacrifice and ultimately, death. Indeed, Julie's death as a consequence of her rescuing a drowning child epitomized her real-life performance of her motherly

$\overline{25}$ Gervaise (1720), I: 249, emphasis added. 
duties. Héloïse's sexual passion, which had been so consistently highlighted in other eighteenth-century retellings of her story, was replaced by another kind of passion, a truly Christ-like passion in which she finally died sacrificing herself for others.

\section{Giovenile Errore: Looking Back on the Medieval}

Toward the end of the novel, Saint-Preux reflected on the spiritual journey he had made in the course of the novel. Describing the sublimation of his love for Julie, he explicitly referred to it as a sacrifice, suggesting that, in spite of everything, his new chaste state was unable to bring him true fulfillment:

Si l'amour éteint jette l'âme dans l'épuisement, l'amour subjugué lui donne avec la conscience de sa victoire une élévation nouvelle, et un attrait plus vif pour tout ce qui est grand et beau. Voudrait-on perdre le fruit d'un sacrifice qui nous a coûté si cher ? Non, Milord, je sens qu'à votre exemple mon cœur va mettre à profit tous les ardents sentiments qu'il a vaincus. Je sens qu'il faut avoir été ce que je fus pour devenir ce que je veux être. (II: 183, emphasis added)

In thus looking back, from a stance of new knowledge, on his former love, SaintPreux echoed the first sonnet in the Petrarchan sequence, where the poet looked back on his sinful passion for Laura:

Voi ch'ascoltate in rime sparse il suono

di quei sospiri ond'io nudriva ' 1 core

in sul mio primo giovenile errore

quand'era in parte altr'uom da quel ch'i' sono. (3, emphasis added)

The Italian "errore" referred both to the geographic wanderings of the protagonist, in the tradition of the Dantean wandering or lost soul, and to the error of his youthful ways. Youth was presented as a state of error, which must be corrected by the wisdom of age. As Rousseau's alter ego R. explained in the Entretiens sur les romans:

Je ne fais point de comparaison entre le commencement et la fin de l'ouvrage. Les détails de la vie domestique effacent les fautes du premier âge : la chaste épouse, la femme sensée, la digne mère de famille font oublier la coupable amante. Mais cela même est un sujet de critique: la fin du recueil rend le commencement d'autant plus répréhensible. (II: 400, emphasis added)

"Premier âge", "moyen âge": the first age of mankind, equated in eighteenthcentury philosophic discourse with the medieval, had to be corrected by historic progress and by later wisdom, but tragically, this wisdom could only be acquired through the protagonists' act of distancing themselves from their youthful, truly lived passion. The medieval as a source of nostalgia, a site where human fulfilment was possible, was not a historical period, and its ultimate tragedy was precisely this location outside of human time. It was neither in the chaste present of the 
quasi-monastic "rule" adopted by Rousseau's fictional lovers, nor in their past, during which — as purely sensual, non-socialized beings - they had not yet been fully cognizant participants in human society.

Rousseau's rewriting of the medieval letters was finally, and paradoxically, both a modernization and an archaization. Rousseau modernized the medieval text by showing how virtue could manifest itself in a contemporary setting, yet at the same time he returned his reader to the original story by insisting on its central subjectthe conversion and redemption of a sinner's soul-whose very possibility he, however, ended up questioning. This new reading was in turn mediated, to an important extent, by Gervaise's previous, revisionary repositioning of the Abélard and Héloïse story within the context of monastic historiography. Moving forward in time, Rousseau reread Abélard and Héloïse's letters through the lens of Petrarch's Marian sublimation of Laura, literally killing off Julie in the process. Moving backward in time, he reread Abélard's text through the critical lens of Augustine. Religion based on ecclesiastical authority, and Abélard's faith in book-learning, was replaced by natural religion or the Augustinian Book of Nature. This double direction of Rousseau's rewriting of his medieval intertexts in La Nouvelle Héloüse, both forward- and backward-looking, was emblematic of the double nature of medievalism itself. The medieval was not a historical, but an ethical category. In this capacity, it served as a polemical, epistemological counter-model, an imaginary point of origin within a larger history of human virtue. Rather than consisting in a collection of identifiable characteristics and attributes, in the manner of a literary genre, it functioned most effectively as a kind of musical mode or register, evoking the memory of a time that had, perhaps, never been, but without whose enticing "chimères" Rousseau's own novel would not exist.

Open Access This article is distributed under the terms of the Creative Commons Attribution Noncommercial License which permits any noncommercial use, distribution, and reproduction in any medium, provided the original author(s) and source are credited.

\section{References}

Alembert, J. Le Rond d', \& Diderot, D. (1751-1765). Encyclopédie, ou Dictionnaire raisonné des sciences, des arts et des métiers (Vol. 17). Paris: Briasson, David l'aîné, Le Breton, Durand.

Anderson, D. L. (1971). Abélard and Héloïse: Eighteenth-century motif. Studies on Voltaire and the Eighteenth Century, 84, 7-51.

Bayle, P. (1740). Heloïse. In P. Brunel, P. Humbert et al. (Eds.), Dictionnaire historique et critique (Vol. 2, pp. 712-717). Amsterdam, Leiden: The Hague, Utrecht.

Challandes, L. (2002). D’Abélard à Julie: un héritage renversé. Annales Jean-Jacques Rousseau, 44, 55-80.

Charrier, C. (1933). Héloüse dans l'histoire et dans la légende. Paris: Champion.

Duperray, E. (1997). L'or des mots. Une lecture de Pétrarque et du mythe littéraire de Vaucluse des origines à l'orée du XXe siècle. Paris: Presses de la Sorbonne.

Feilla, C. (2004). From "sainted maid" to "wife in all her grandeur": Translations of Heloise, 1687-1817. Eighteenth-Century Life, 28(2), 1-16.

Gervaise, F. A. (1720). La vie de Pierre Abeillard, abbé de S. Gildas de Ruis, Ordre de S. Benoist, et celle d'Heloïse son epouse, premiere abbesse du Paraclet. Paris: Jean Musier, François Barois.

Gervaise, F. A. (1723). Les veritables lettres d'Abeillard et d'Heloise, tirées d'un ancien manuscrit Latin trouvé dans la Bibliotheque de François Amboise Conseiller d'Etat. Paris: Jean Musier. 
Hamman, C. (2006). La vie de Jean-Jacques Rousseau ou l'éternel retour du Tasse. Revue d'histoire littéraire de la France, 106, 4.

Holsinger, B. (2005). The premodern condition: Medievalism and the making of theory. Chicago: University of Chicago Press.

Kamuf, P. (1982). Fictions of feminine desire: Disclosures of Hélö̈se. Lincoln: University of Nebraska Press.

Koschorke, A. (2000). Joseph, Abélard, Saint-Preux. In Die heilige Familie und ihre Folgen. Ein Versuch. Frankfurt: Fischer Taschenbuch Wissenschaft.

L'Aminot, T. (2002). L'amour courtois dans La Nouvelle Héloüse. In C. Piau-Gillot, R. Desné, \& T. L'Aminot (Eds.), Modernité et pérennité de Jean-Jacques Rousseau. Mélanges en l'honneur de Jean-Louis Lecercle (pp. 241-257). Paris: Honoré Champion.

Leborgne, E. (2002). De Saintré à Saint-Preux: culte amoureux et vassalité dans la première partie de $L a$ Nouvelle Héloüse. Annales Jean-Jacques Rousseau, 44, 81-99.

McDonald Vance, C. (1973). The extravagant shepherd. A study of the pastoral vision in Rousseau's Nouvelle Héloïse. Banbury: The Voltaire Foundation.

Montoya, A. C. (2010a). Naturalizing the commonplace. Two readings of Tasso during the long eighteenth century (Sévigné, Rousseau). In J. Koopmans \& N. H. Petersen (Eds.), Legitimation of Authority. Leuven: Peeters (forthcoming).

Montoya, A. C. (2010b). Medievalism and enlightenment, 1647-1750 (Jean Chapelain to Jean-Jacques Rousseau). The Romanic Review (forthcoming).

Petrarca, F. (1992). R. Antonelli, G. Contini, \& D. Ponchiroli (Eds.), Canzoniere. Turin: Einaudi.

Powell, M. (2000). Listening to Heloise at the Paraclete: Of scholarly diversion and a woman's "conversion". In B. Wheeler (Ed.), Listening to Heloise: The voice of a twelfth-century woman (pp. 255-286). New York: St. Martin's Press.

Riley, P. (2004). Character and conversion in autobiography: Augustine, Montaigne, Descartes, Rousseau, and Sartre. Charlottesville: University of Virginia Press.

Rousseau, J. J. (1973). B. Gagnebin \& M. Raymond (Eds.), Confessions. Paris: Gallimard.

Rousseau, J. J. (1993). H. Coulet (Ed.), La Nouvelle Héloüse. Paris: Gallimard.

Rousseau, J. J. (1995). Dictionnaire de musique. In B. Gagnebin \& M. Raymond (Eds.), Euvres complètes (Vol. 5). Paris: Gallimard.

Spaas, L. (1999). Rousseau et Abélard: la structure patriarcale menacée. In T. L’Aminot (Ed.), JeanJacques Rousseau et la lecture (pp. 107-116). Oxford: Voltaire Foundation.

Stackelberg, J. (2001). Du paysage de l'amour au paysage de l'âme: Pétrarque et Rousseau. In P. Aron, $\mathrm{S}$. Basch et al. (Eds.), Vérité et littérature au XVIIIe siècle. Mélanges rassemblés en l'honneur de Raymond Trousson (pp. 265-270). Paris: Honoré Champion.

Starobinski, J. (1971). Jean-Jacques Rousseau. La transparence et l'obstacle. Paris: Gallimard.

Starobinski, J. (1994). Rousseau e Tasso: lezione sapegna 1993. Turin: B. Boringhieri.

Stewart, P. (1995). Half-Title, or Julie Beheaded. The Romanic Review, 86, 36-43.

Walter, E. (1980). Le complexe d'Abélard ou le célibat des gens de lettres. Dix-huitième siècle, 12, $127-152$. 